\title{
The Use of English in Teaching Mathematics and Science: The PPSMI Policy vis-à-vis The DLP
}

\author{
Melor Md Yunus \\ Faculty of Education, The National University of Malaysia (UKM), Malaysia \\ E-mail: melor@ukm.edu.my \\ Saiful Islam Ahmad Sukri (Corresponding author) \\ Faculty of Education, The National University of Malaysia (UKM), Malaysia \\ E-mail: saifulislamahmadsukri@yahoo.com
}

Doi:10.7575/aiac.alls.v.8n.1p.133

URL: http://dx.doi.org/10.7575/aiac.alls.v.8n.1p.133
Received: $11 / 10 / 2016$

Accepted: 22/01/2017

\begin{abstract}
In spite of English being regarded as the second most important language in Malaysia, it is still treated as a foreign language inevitably. The recently introduced Dual Language Progamme (henceforth DLP) which uses English as the medium of instruction in teaching Mathematics and Science is alleged to be a reflection of the less successful English for teaching Mathematics and Science policy (hereafter PPSMI). Therefore, this paper aims to examine the perceptions of pre-service teachers towards the use of English in teaching Mathematics and Science and establish its connections with the DLP. Data were collected through questionnaire which involved 50 respondents. Findings showed that the respondents held unfavourable perceptions of the PPSMI policy which in turn justified the emergence of the DLP. Implications of the study and suggestions for future research are also discussed.
\end{abstract}

Keywords: English for teaching Mathematics and Science, Dual Language Programme, Education, Educational Policy, Pre-service teachers

\section{Introduction}

In this age and day, individuals who arm themselves with a good command of the English language are likely to enjoy more benefits and privileges than their counterparts who are less proficient in English. This is because mastering English is of paramount importance in helping a nation to progress to its greatest heights and thus, firmly retaining its world-class competitiveness and productivity in the global arena. According to the former Prime Minster of Malaysia, Tun Mahathir Mohamad cited in Joash (2015), the country's ability to survive and thrive would be in jeopardy if the future generations of Malaysia are not well-versed in English, the language of commerce and trade. Over the course of time, there have been many instances reflecting the immense importance of English. For example, the Japanese manufacturing car company, Honda, after years of its operations across the world, lastly resorts to making English as its corporate lingua franca (Oh, 2015). Of late, the Sultan of Johor himself has proposed an idea to reintroduce Englishmedium schools on which English becomes the main medium of instruction in subjects deemed to expeditiously impart the content knowledge in English (Killi, 2015; Kok, 2015). Thereby, the English language is seen as a tool instrumental for the advancement and most importantly for the survival of the country in the nearest future.

However, the proficiency of the English language among Malaysians has not seen much improvement since 1970. There have been a number of measures undertaken to address the deterioration in the English language and one of which is the teaching of Mathematics and Science in English policy or known as (PPSMI). The Education Ministry of Malaysia implemented the aforesaid educational reform in 2003 with the aims of improving students' command of English and accelerating their mastery in Science and Mathematics. Throughout the implementation of the PPSMI policy, the public have ambivalent attitudes towards it. On one hand, there are people especially the well-educated city dwellers who view it as one of the best platforms to be competent in the international language and produce the quality workforce of tomorrow. They are of opinion that Malaysians should not be pessimistic nor selfish to blatantly disregard the importance of the English language. Adding to that, they opine that the lack of the English language skills would be a great loss to the country and at present, the escalating pressure is felt as social media every now and then report on Malaysians' unfathomable, baffling poor grasp of English. On the other hand, through the lens of the less-privileged segment of a society, they believe that the policy undermine the role of the Malay language as the national language and students at rural schools in particular are faced with difficulties of learning Mathematics and Science in English. After weighing the pros and cons of the PPSMI policy, the then Minister of Education, Tan Sri Muhyiddin Yassin announced that the "soft-landing" approach would be adopted; the Malay Language as the language of instruction would be used in teaching Mathematics and Science by 2016 at the primary school level and 2021 at the secondary school level. 
Nevertheless, the announcement made by the Prime Minister of Malaysia, Datuk Seri Najib Razak during the 2015 budget tabulation caught many by surprise (Kulasagran et al., 2014). According to him, English would never cease being the medium of instruction in the teaching and learning of Mathematics and Science because the Dual Language Programme (DLP) would be implemented in the beginning of 2016. Suffering the same fate as PPSMI, the introduction of the DLP has caused much heated debate as its implementation is said to bring about catastrophic impacts on both the teachers and students as evidenced by the flawed practice of the PPSMI policy (Arsad, 2015; Atan, 2015). In fact, since 2003, some prominent figures have not stopped criticizing the teaching of Mathematics and Science in English policy and, the implementation of the DLP undoubtedly has certainly added fuel to the raging fire. Contrary to the belief held by the nationalists, the government's recent move to use English for the teaching of Mathematics and Science through the DLP is applauded by the English advocates. To them, in lieu of politicizing and constantly attacking the reform, this momentous decision has to be respected and embraced by all the stakeholders. In reality, the emergence of the (DLP) as outlined in the first version of the DLP draft (2015) is completely far cry from the PPSMI policy whereby the DLP does not impose the mandatory use of English on the teaching of Mathematics and Science. Instead, it offers the schools, teachers, students and parents choices of their preferred medium of instruction. Notwithstanding, both the DLP and PPSMI share one thing in common which is they still espouse the notion of using English as a vehicle of disseminating information on Mathematics and Science. In view of that, many have questioned the real motive behind the resurgence of English being the language of instruction despite its ineffectiveness in aiding students ace Science, Mathematics and English and this drove the researcher to conduct a study on the issue concerned and with the data gleaned from the study, it could provide a better understanding as to why the DLP comes into being.

So, the aims of this study are to examine the perceptions of pre-service teachers on the use of English and its stumbling blocks in teaching Mathematics and Science. So as to facilitate this investigation, the research questions were formulated as follows: 1) What are the perceptions of pre-service teachers of Mathematics, Biology, Chemistry and Physics towards the teaching of Mathematics and Science in English? and 2) What are the problems faced in the teaching of Mathematics and Science in English. These two questions would also be discussed in relation to the existence of the DLP.

\section{Literature Review}

\subsection{Revisiting the PPSMI}

The year 2002 witnessed a significant milestone in the field of education. This is because the policy of teaching Mathematics and Science in English or better known by its Malay acronym PPSMI was introduced by the fourth Prime Minister of Malaysia, Tun Mahathir Mohamad. The inception of the PPSMI policy came about as a result of the cabinet meeting on July, $19^{\text {th }} 2002$. This policy was aimed at expediting students' mastery in Science and Mathematics as well as empowering students' command of the English language. It was effective in 2003 with pupils of Year 1 in primary schools and Form 1 and Lower 6 students in secondary schools as the pioneer cohort. It was fully implemented in 2007 for secondary schools and 2008 for primary schools. According to Pandian and Ramiah (2004), the government made a right decision to change the mode of instruction for the teaching of Mathematics and Science. Additionally, this change is expedient for significant developments and better understandings in an acquisition of second language that places a strong emphasis on the role of meaningful, incomprehensible input. Thereby, it could be deduced that teaching Mathematics and Science in English would set a more meaningful context for genuine language use and thus, serving a pivotal point whereby oral language and literacy in English can significantly be developed (Kesseler \& Quinn, 1987).

PPSMI, in reference to Jamaluddin (2008), was a good move in providing the future generations with world class education that would help them survive onerous challenges in an epoch of technological and scientific outbursts. This is very self-evident that the English Language has become a paramount requirement for job-seekers to secure their dream jobs. On top of that, the Curriculum Development Centre cited in Ali and Ismail (2006) reiterated that English,being a mode of instruction for teaching Mathematics and Science, would help secondary school students to keep pace with the latest scientific and technological knowledge. This is because a massive corpus of knowledge in reference books and recent discoveries are often reported in English. Even if there were translated versions of the textbooks, the quality of the contents would not be up-to-date. As acknowledged by Thang and Olaybal (2006), the process of translating scientific terms from English to Malay is laborious and as a consequence, the translated materials become outdated. Another issue raised by David \& Govindasamy (2005) is the inappropriateness of the Malay language for academic purposes, considering its progress at that point in time.

As mentioned earlier, the PPSMI policy had never stopped being the subject of grave concern since some were totally against it due to various reasons. It was a well-known fact that the "top-down" PPSMI policy took place without consulting Ministry of Education officers and most vitally, the teachers who are the implementers of the policy. Such practice was chastised by Samah (2008) as it was executed without considering expert educational opinions. After taking several matters into consideration, nevertheless, the former Minister of Education, Tan Sri Muhyiddin Yassin announced that PPSMI would be completely abolished in 2014. Due to this decision, the instructional medium of teaching and Mathematics and Science would be reverted to the Malay language. This notable shift was very much needed as students in the rural school were found to suffer from PPSMI (Mohandas, 2009). Moreover, researches conducted in government schools showed that less than 5 percent of classes fully taught Mathematics and Science in English at the primary school level and less than nine percent exercised PSSMI as desired at the secondary school level 
(Hamid, 2011). Yet, there are still unhappy voices heard over the reversal of the medium of instruction as they are adamant about using English to teach Mathematics and Science.

\subsection{Past Studies on PPSMI}

Teaching Mathematics and Science in the Malay language was claimed not to be advantageous to students. According to the chairman of the Parent Action Group for Education, Datin Noor Azimah Abdul Rahim (2010), using the Malay language in teaching Mathematics and Science would further weaken the students' command of English. It is crystal clear that Malaysian students' command of English has dropped dramatically since 1970. Some have been jobless for a considerable period of time. This circumstance is meant to portray the importance of the English Language that should not be taken lightly. In other words, a lot of emphases should be placed on empowering the English language as it is a boon to achieve development and gain knowledge (Thirusanku and Yunus, 2014). In fact, the use of English in teaching Mathematics and Science should be a channel to heighten the people's awareness of the English language. This is because as reported by Chan and Abdullah (2015), many had not yet realised added advantage of being bilingual even though they held positive attitudes towards bilingual education. Adding to that, many Malaysian students including top scorers in public examinations experienced difficulties coping with tertiary studies due to their low level of English proficiency. This is because most learning materials are written in the English language and it is not surprising if they are not able to comprehend the lessons studied. Recently, many excellent students in Terengganu had turbulent times attaining the required band in the Malaysian University English Test (MUET) prior to being accepted as students at local universities (The Star, 2010). Thus, Datin Noor Azimah Abdul Rahim (2010) stressed that the PPSMI should not be abolished by any means. Instead, it should be continued for the benefit of the students in the years to come. This could be done by introducing dual language education and the school should decide the choice of the language used in teaching Mathematics and Science (Azimah, 2013). This suggestion speaks some truth as Lindholm-Leary (2016) postulated that dual language students fared well in language proficiency skills and developed fondness for the language and speaker of the target language. Moreover, Saalbach et al (2014) pointed out that using English alongside the mother tongue went beyond achieving communicative competence; improved ability of executive control in balanced and unbalanced billinguals. Contrary to popular belief, below average students in immersion were found to perform significantly higher on all second language (L2) measures than the below average students in the monolingual L1 program who received conventional L2 instruction (Genesse and Fortune, 2014). Considering these studies, the use of English has proven to be of great value and defied some misconceptions about it but still many are being skeptical about its suitability to teach Mathematics and Science in the context of Malaysian education system.

Having abolished the PPSMI policy, many parties concerned would be affected and had to quickly adapt to the new policy. Not only did this affect the whole system, but it also left teachers and students feeling no less than lab rats. In consequence, students, who used to learn Science and Mathematics in English, had to be mentally and cognitively prepared for the change in the medium of instruction. At the same time, they might get confused and consequently, their academic performance might be adversely affected. This is due to the fact that reverting to the national language resulted in students failing to perform globally (Nor \& Aziz, 2008). The late Chief Minister of Sarawak, Tan Sri Adenan Satem condemened such move when he said "We don't want a situation where this year, we use the English language and next year, we go back to the Malay language. There needs to be consistency so that it would not confuse the students and parents" (Pim, 2016). Besides, in a study by Mohandas \& Rajaratnam (2015), students whose English proficiency was better performed better in Mathematics and Science. According to Muda et al. (2012), if the reversal of the language of instruction were to take place, it would not be a laudable action. This is because university students benefitted from the policy as it helped them enhance their English proficiency. A positive attitude towards enhancing the use of English at tertiary level also emerged from a study of Yunus and Hern (2011).

However, Professor Emeritus Ungku Aziz cited in Hussain \& Hamid (2009) claimed that the government's decision to abolish the PPSMI policy was undoubtedly a wise decision and gave great gratification to most Malaysians. In his opinion, Mathematics and Science can be taught in Malay as it is a better medium of instruction to effectively impart mathematical and scientific knowledge to students. In the same vein, Majid et al. (2011) claimed that the National University of Malaysia (UKM) over the years had successfully churned out thousands of excellent graduates in medicines, engineering, sciences and law with Malay being the language of knowledge.

On top of that, Ridhwan (2009) disdained the PPSMI policy as it was believed to create a vast gap between Malaysians; one group who had high proficiency of English is specialized in the field of science and technology and another group who was proficient in Malay was labeled as low class citizens since their expertise was on subjects of literature and social science. If this were to happen, it would not only discriminate the latter group but also hamper the government's effort to unite all Malaysians of different mother tongue, races, religions, customs and traditions. In Indonesia, for example, citizens of the upper class society who communicated in English were highly respected whereas others who were non-English speakers were looked down upon and therefore aggravated the tension between them (Onishi, 2010). This implies to Malaysians that they must view the Malay language as the language of solidarity which they ought to be proud of. As such, it might not put some marginalized groups at disadvantage. This can be traced to a study of Planas and Civil (2013) where students whose dominant language differed from the language of instruction were likely to withdraw from taking part in whole-class discussions.

Pandian and Ramiah (2004) concluded that Mathematics and Science teachers were prone to using the Malay language when faced with difficulty in explaining concepts to their students and therefore, they were in dire need of intensive 
language support. Besides, the use of the Malay language helped students understand concepts taught better since their English proficiency was extremely weak and such strategy was found prevalent in a study by Salam and Shahrill (2014). In addition to that, the textbook was believed to be rather brief with insufficient examples and therefore was not useful especially for low English proficiency students. Not only was the textbook unhelpful for low English Proficiency students, the multimedia courseware was unsuitable for them either. One of the teachers pointed out that "The CDs are good but my students do not understand so I have to stop and translate for them". In a study undertaken by Isa et al. (2010), students from the Faculty of Education and Faculty of Science and Technology at UKM chose the Malay language as the more effective language of instruction in teaching Mathematics and Science. Another finding was also reported by a study of Idris et al. (2007) whereby teachers asserted that they needed more preparations to overcome students' language difficulties when teaching Mathematics and Science in English. Based on the above, it clearly signifies that the top-down flawed policy is often beset with its arduous challenges and further verified by Palmer et al. (2014) where a "one-size fits all" model does succumb to problems in different contexts.

In support of abolishing PPSMI, Nor Hashimah Jalaluddin, the professor at the Faculty of Social Sciences and Humanities, UKM expressed her concern that the belief of improving students' English proficiency through the PPSMI policy was a myth. Her research in 2007 depicted that the level of English proficiency amongst the students in Johor after the implementation of the PPSMI policy remained the same. It was also alarming in the sense that students were neither able to communicate in English nor equipped with sufficient vocabulary to construct even simple sentences. These findings are supported by the Relevance Theory which states that knowledge is best acquired in one's mother tongue. Moreover, Reljic, Ferring \& Martin (2014) demonstrated that the use of the first or native language was widely acknowledged because it was beneficial to instill confidence in children, enhance their academic performance, and ensure the survival of linguistic diversity, heritage, etc. Thus, the decision to make use of the Malay language in teaching Mathematics and Science should be welcomed wholeheartedly by all.

In reference to the report of the Sultan Idris Education University by Haron et al. (2008) involving 75\% of the pupils from 68 primary schools, there were a slew of negative results and weaknesses found in the implementation of PPSMI. One of the chief problems was teachers' lack of linguistic proficiency in English. The repercussion was they were neither successful to facilitate the learning and performance of students nor improve the students' mastery of English. So, the report encapsulated that Mathematics and Science were not the best tools to improve English proficiency. Nevertheless, the findings of the Sultan Idris Educational University report were lambasted for their validity and reliability. Jantan (2008) alleged that the research design was flawed and the researchers made unfounded conjectures. Evidently, the researchers" choice on the concept of "hard to understand" and "understand" were invalid since none of the above concepts was behaviourally measurable. Albeit the flawed research design, it in fact did serve an eye opener to the public about the current state of the PPSMI policy. He strongly supported that PPSMI should be continued but with some changes. Prior to learning Mathematics and Science in the English Language, he was of opinion that the learning of Science and Mathematics must be done in Malay in the first 4 years of a pupil's primary education because at the early stage, he or she could learn numeracy and science skills better in his or her first language. Furthermore, the UNESCO study reported that students could learn lessons best in their mother tongue in the primary stages of schooling (Ball, 2014).

\subsection{The Dual Language Programme (DLP)}

In essence, the DLP is part of the upholding the Malay language and strengthening the English language policy. This programme basically gives an option for students to choose their preferred medium of instruction either the English language or the Malay language in learning the subjects offered such as Mathematics, Science, Information and Communication Technology and Design and Technology. The DLP is in alignment with one of the goals in the National Education Blueprint (2013-2025) which aspires to produce students who are at least bilingual in the Malay language and English language. It is believed that the DLP could enable Malaysians to easily get access to a wealth of knowledge and thus, being recognised as a driving force for the development of a country. In 2016, there are 300 out of 10,154 primary and secondary school implementing the DLP and in the future, it is predicted that more schools would be applying for the DLP (Menon, 2016). As of now, the DLP involves standard 1 and 4 at primary level and form 1 at secondary level. Unlike PPSMI, the implementation of the DLP is upon the school's request. Nevertheless, to put the DLP into practice, there are 4 conditions that schools must fulfill (Education Ministry of Malaysia, 2015). First, they should have sufficient resources. Second, the DLP can take place after getting the green light from the principal and teachers. Third, parents' support and request for the DLP also play a role in meeting the pre-determined requirement of the DLP. Lastly, the aspiring schools must ensure their performance in the Malay subject is on a par or better than the national average grade at the Malaysian Education of Certificate "Sijil Pelajaran Malaysia" level.

It is believed that there are a few factors that give impetus to the DLP. One of the prominent reasons is because of the growing demands from parents who want their children to learn Mathematics and Science in English. These demands are inextricably linked with the impact of unstoppable globalization and thus, affecting every facet of the people's lives (Aziz and Nair, 2015). To them, studying Mathematics and Science in English does facilitate their understanding better than in Malay. This is due to the fact that the use of English allowed them to absorb scientific knowledge fast besides preparing themselves for scientific higher education (Rahim, 2013). Additionally, according to Education Ministry of Malaysia (2010) cited in Ahmad et al. (2012) disclosed that approximately only $25 \%$ of teachers were found to be fit and competent to teach Science and Mathematics in English.Apart from that, the government of today is very much 
concerned with the erosion of English competency plaguing the university graduates. It is a lamentable fact that their poor grasp of the English language coupled with dearth of generic skills explains why they end up being jobless after completing their tertiary studies. This problem has never ceased to exist and it seems that the language progress made by the Malaysian graduates has not been very promising. Lately, the decline in English has not only been experienced by the students but also the English teachers across the country. This can be seen wherein two-thirds of 70,000 English teachers did not meet the minimum requirement of the English language proficiency based on their results in the English language proficiency test conducted by the Malaysia's Ministry of Education in collaboration with the British Council (Jalleh, 2012). Therefore, it comes as no surprise when the English Language Standards and Quality Council (2016) affirms the fact that the level of English proficiency amongst Malaysians is in "a chronic state". Another example of English being the stumbling block that hinders one from achieving success in their future job can be seen when more than 1,000 doctor trainees quit their studies partly due to poor English (Murali, 2015). Their poor command of English could be depicted in their incapability to communicate in English well. This matter is further exacerbated because most reference books on medicine and lectures are available and taught in English. With all the pandemic scenarios above, it posits that the government's attempt of bolstering the quality of English has yet to come to a fruition. So, through the implementation of the DLP, it highlights the government's continuous effort to support the use of English for its immense importance but at the same time concerned with the needs of less privileged students or even teachers. This is congruent with a study of Selamat et al. (2010) which concluded that PPSMI could be implemented but not $100 \%$; the use of both the Malay and English for the teaching of Mathematics and Science. Hence, this study is worth conducted as it would unearth the perceptions of pre-service teachers of Mathematics, Biology, Chemistry and Physics at a public university in Malaysia towards the teaching of Mathematics and Science in English and the challenges faced in the teaching of Mathematics and Science in English.

\section{Methodology}

\subsection{Research Design}

The study employed a survey in which the researcher collected both quantitative and qualitative data simultaneously with the aims of examining the perceptions and challenges faced by pre-service teachers of Mathematics, Biology, Chemistry and Physic in the teaching of Mathematics and Science in English. Among the reasons for adopting the survey research are it can be used to answer different types of research questions from multiple angles and data can quickly be collected (Piaw, 2016).

\subsection{Respondents}

The respondents of this study were comprised of 50 pre-service teachers majoring in Mathematics, Biology, Chemistry and Physics at the public university in Malaysia. They basically learnt Mathematics and Science in both the English language and Malay language Among the 50 respondents, $9(18 \%)$ were males and $41(82 \%)$ were females. The respondents ranged in age from 22-29. All the subjects have received the English language education for 11 years since primary school. They underwent their teaching practice at assigned secondary schools all over Malaysia. In particular, 19 were stationed at urban schools, 25 at semi- urban schools and 6 at rural schools. The students that they taught were mostly intermediate learners of English.

\subsection{Instrument}

The questionnaire items were adapted from the studies of Pandian and Ramiah (2004) and Zaidi et al. (2011). The questionnaire consisted of two sections: 1) their perceptions towards the teaching of Mathematics and Science in English and 2) challenges faced when teaching Mathematics and Science in English. The first section contained 8 closeended items whereas the second section was made up of 5 close-ended items and 1 open-ended item. The close-ended items were measured based on nominal scale; Yes, No, and Unsure. The open-ended item was purposely created to understand deeply about the ordeals that they went through during their 2-month teaching practice at respective schools. Moreover, their feedback to the open-ended item was categorized, coded and analysed depending on the extracted themes.

\subsection{Data Collection Procedures and Analysis}

Before proceeding to an actual study, a pilot study was conducted whereby a total of 15 Mathematics, Biology, Chemistry and Physics pre-service teachers were selected to answer items in the questionnaires given. Majority of them took around 10 minutes answering the questionnaires. Based on the feedback obtained, it showed that all of them had no difficulty responding and giving answers to a number of questions asked. On the day of collecting actual data for the study, before answering the questionnaires, the researcher informed the students about the purpose of the research and gave a briefing on how to go about the questionnaire. All of them managed to fully answer all the items in the questionnaires and all the data obtained were then reported in frequency counts and percentages. 


\section{Findings}

Table 1. Pre-service teachers' perceptions towards the PPSMI policy.

\begin{tabular}{|c|c|c|c|c|c|c|}
\hline \multirow[t]{3}{*}{ Items } & \multicolumn{6}{|c|}{ Responses } \\
\hline & \multicolumn{2}{|c|}{ No } & \multicolumn{2}{|c|}{ Unsure } & \multicolumn{2}{|c|}{ Yes } \\
\hline & $\mathrm{F}$ & $\%$ & $\mathrm{~F}$ & $\%$ & $\mathrm{~F}$ & $\%$ \\
\hline $\begin{array}{l}\text { 1. Do you agree that English is the international language of } \\
\text { communication and language of technology? }\end{array}$ & 6 & 12 & 0 & 0 & 44 & 88 \\
\hline $\begin{array}{l}\text { 2. Do you agree that Science and Mathematics should be taught } \\
\text { in English? }\end{array}$ & 29 & 58 & 4 & 8 & 17 & 34 \\
\hline $\begin{array}{l}\text { 3. Do you agree that the use of English for teaching Mathematics } \\
\text { and Science can significantly improve the students' command of } \\
\text { English? }\end{array}$ & 20 & 40 & 10 & 20 & 20 & 40 \\
\hline $\begin{array}{l}\text { 4. Do you think the use of English for teaching Mathematics and } \\
\text { Science is troublesome to both teachers and students? }\end{array}$ & 7 & 14 & 6 & 12 & 37 & 74 \\
\hline $\begin{array}{l}\text { 5. In your opinion, are you ready to teach Science/Mathematics } \\
\text { in English? }\end{array}$ & 15 & 30 & 8 & 16 & 27 & 54 \\
\hline $\begin{array}{l}\text { 6. Do you agree with the claim made by Professor Emeritus } \\
\text { Ungku Aziz that Science and Mathematics can actually be taught } \\
\text { in the Malay language? }\end{array}$ & 0 & 0 & 6 & 12 & 44 & 88 \\
\hline $\begin{array}{l}\text { 7. Is reverting instructional mode back to the Malay language in } \\
\text { teaching Science and Mathematics a wise decision made by the } \\
\text { Government? }\end{array}$ & 8 & 16 & 12 & 24 & 30 & 60 \\
\hline $\begin{array}{l}\text { 8. Do you agree that the reversal of instructional medium for } \\
\text { teaching Science and Mathematics will inflict a heavy burden as } \\
\text { you have been trained to teach those subjects in English for a } \\
\text { period of time? }\end{array}$ & 30 & 60 & 6 & 12 & 14 & 28 \\
\hline
\end{tabular}

Note: F: Frequency

The following table displays the respondents' perceptions towards the PPSMI policy. On the whole, pre-service teachers' perceptions towards the PPSMI policy were not positive so they supported the government's decision to revert the instructional mode from English to the Malay language to teach Mathematics and Science. As displayed in the above table, more than half of them (58\%) were not in favour of teaching Mathematics and Science in English (item 2). Inconsistent with their displeasure at PPSMI, it was discovered that majority of them (88\%) were in agreement with the idea of using the Malay language in teaching Mathematics and Science as supported by Professor Emeritus Ungku Aziz (item 6). More importantly, $74 \%$ of them found the implementation of PPSMI not only troublesome to teachers but also students (item 4). They probably arrived at such conclusion by reflecting on their teaching practicum experiences in which they had to transmit knowledge of Mathematics and Science in English. The ordeals that PPSMI had imposed on them could explain why $60 \%$ of them viewed the government's decision to change the medium of instruction to the Malay language as a wise act (item 7) and their stance was further reflected in item (8) in which more than half of the respondents believed that the reversal of the medium of instruction would not burden them although they have been trained to teach Mathematics and Science in English for almost 4 years.

Less than half of the respondents $(40 \%)$ did not subscribe to the belief that the implementation of the PPSMI policy could significantly improve the students' command of English (item 3) even though most of them (88\%) opined that English is the international language of communication and the language of technology (item 1). Despite their negative perceptions towards PPSMI, 54\% of them were ready to teach Mathematics and Science in English (item 5). This is because some of them have been exposed to PPSMI since they were at secondary school.

Table 2. Challenges faced when teaching Mathematics and Science in English

\begin{tabular}{|c|c|c|c|c|c|c|}
\hline \multirow{4}{*}{$\begin{array}{l}\text { Items } \\
\text { 1. Did you face any difficulties teaching } \\
\text { Science/Mathematics in English during your } \\
\text { teaching practicum? }\end{array}$} & \multicolumn{6}{|c|}{ Responses } \\
\hline & \multicolumn{2}{|c|}{ No } & \multicolumn{2}{|c|}{ Unsure } & \multicolumn{2}{|c|}{ Yes } \\
\hline & $\mathrm{F}$ & $\%$ & $\mathrm{~F}$ & $\%$ & $\mathrm{~F}$ & $\%$ \\
\hline & 11 & 22 & 5 & 10 & 34 & 68 \\
\hline $\begin{array}{l}\text { 2. If yes, please state the difficulty (ies) that you } \\
\text { faced during the teaching practicum. }\end{array}$ & \multicolumn{2}{|c|}{ Poor English } & \multicolumn{2}{|c|}{ Low self-esteem } & \multicolumn{2}{|c|}{$\begin{array}{c}\text { Translating } \\
\text { notes }\end{array}$} \\
\hline & $\mathrm{F}$ & $\%$ & $\mathrm{~F}$ & $\%$ & $\mathrm{~F}$ & $\%$ \\
\hline & 25 & 73.53 & 6 & 17.65 & 3 & 8.82 \\
\hline & \multicolumn{2}{|c|}{ No } & \multicolumn{2}{|c|}{ Unsure } & \multicolumn{2}{|c|}{ Yes } \\
\hline 3. Did you employ any code-switching (mixing & $\mathrm{F}$ & $\%$ & $\mathrm{~F}$ & $\%$ & $\mathrm{~F}$ & $\%$ \\
\hline $\begin{array}{l}\text { the English and Malay languages) in teaching } \\
\text { Science/Mathematics during your teaching } \\
\text { practicum? }\end{array}$ & 8 & 16 & 2 & 4 & 40 & 80 \\
\hline
\end{tabular}


4. Did your students ask you to teach

Science/Mathematics in the Malay language instead of the English Language?

5. Based on your experience during the teaching practicum, do you think the students learnt Mathematics and Science in the English language better than in the Malay language?

6. Given an option between Malay and English, which language do you prefer to use in teaching Science and Mathematics?

Note: F: Frequency

The table below underscores respondents' challenges in teaching Mathematics and Science in English. As shown in Table 2, it is unarguable that the respondents were faced with vicissitudes of the PPSMI policy. This could be seen in item 3 where $68 \%$ of them admitted to experiencing difficulties to teach Science and Mathematics in English throughout their 2-month teaching practicum (item 1). There were three major difficulties hampering the respondents from a smooth execution of the PPSMI policy (item 2). The major contributing factor was students' poor command of English. The students' low level of self-esteem when communicating in English and constant preparations of translating notes for students were also other inhibiting factors to the success of PPSMI. On account of that, majority of the respondents (80\%) resorted to code-switching while teaching Mathematics and Science in English (item 3). Moreover, a large number of them $(82 \%)$ encountered students' requests to teach Mathematics and Science in the Malay language rather than in the English language (item 4). In consequence, this made $62 \%$ of the respondents claim that students did not learn Mathematics and Science better in English (item 5). After all, if given a chance, $80 \%$ of them would be more comfortable to utilise the Malay language at their disposal as the medium of instruction to best teach Mathematics and Science (item 6).

\section{Discussion}

In this section, the findings of the study are discussed in relation to the introduction of the DLP. Based on this study, majority of the respondents possessed negative perceptions of PPSMI. As outlined by many previous researches including Samah et al. (2008) and Palmer et al. (2014), this proves the fact that the top-down approach as exercised in the PPSMI implementation often times did not attain its desired effects. However, this did not stop the government from rectifying the mistakes made and without looking back anymore, it devised the DLP which is deemed as a solution to approach the teaching and learning of Mathematics and Science. Even though the presence of the DLP is associated with the failures of PPSMI, it indirectly mirrors the maturity, understanding and tolerance of the government of today in providing what benefits students the most as recommended by Jantan (2008), Rahim (2010) and Rahim (2013). As elucidated earlier, the DLP can only be put into practice after fulfilling all the prescribed conditions set by the Ministry of Education. In other words, the modus operandi of the DLP is different from PPSMI and because of that, the DLP should not be blindly mistaken for PPSMI.

The other invaluable input derived from the study is the instrumental value of the Malay language that has been deeply rooted or ingrained in the minds of Malaysians. This could be traced to their beliefs that they look up highly to the Malay language even in the communication and technology age. It is not merely a language that fosters solidarity among Malaysians but it is also regarded as an effective means of learning subject matters that are by nature complex. Therefore, in this context, it enlightens complicated concepts that are difficult to be understood in English better in Malay. This is very apparent when teachers employ code-switching and such strategy is found to be ubiquitous as reported by Pandian and Ramiah (2004). In a similar fashion, a study by Salami and Shahrill (2014) also yielded the similar finding as it aided students' comprehension but they cautioned that students did not necessarily learn better when their teacher code-switched during the lesson. This is further asserted by Saalbach et al (2014) in which the information learned in one language might not be retrieved in another language. So, with the DLP being put into practice, this should not be an issue that continues to be politicized by some parties as it does neither deny nor forbid them from receiving Science and Mathematics education in the language that they are comfortable with. In essence, the DLP is ideally a better approach to teaching Mathematics and Science as it without fail takes cognizance of students' preferred mode of communication and most importantly, acknowledges the important roles that the national language play in a multi-cultural country.

On a different note, the findings could be viewed as the resistance of most Malaysians to change. Their preference for the Malay language over the English language is one of the many instances that they are very much within their comfort zones. As delineated above, even though more than half of them are prepared to teach Mathematics and Science in English, the tumultuous times they had with the PPSMI policy could be said to dampen their level of interest and motivation. As a result, this contributed to their unwillingness to change for students' interests shall never be compromised in any way. If students gained nothing from the PPSMI policy, they did not see any reason why they should strictly adhere to what the said policy had dictated to them. This is illustrated by Palmer et al. (2014) whereby many teachers completely abandon the policy and stick to monolingual education. In fact, they strongly believe that students' command of English is not possible to be enhanced via the PPSMI policy as students are still struggling to master English, what more learning Mathematics and Science in English. This finding is also consistently reported by 
Jalaluddin (2007), Idris (2007) and Isa et al. (2011) wherein the use of English in learning Mathematics and Science put students at stake. Despite that, the data revealed that more than 30 percent of respondents supported the use of English for teaching Mathematics and Science. This is in sync with the study of Selamat et al (2010) which did not entirely blame for the notion of English being the language of instruction in teaching Mathematics and Science but rather on its faulty and erroneous implementation. In fact, the idea behind it is of great interest. This sentiment is also shared by Rahim (2013) who was unceasingly vying for the resurgence of English in teaching Mathematics and Science. On top of that, the exposure to the DLP should reach below average or even at-risk students since they were found to benefit from it and it is imperative for them to acquire invaluable language and cultural skills for their future lives (Genesse \& Fortune, 2014). So, again, the DLP which is the rebirth of the PPSMI policy is not something that shatters the equilibrium in today's education system but a concerted commitment towards modernization in education in a more diplomatic manner that everyone will come to terms with sooner or later.

\section{Conclusions and Implications}

Considering the above research findings and discussion, it can be concluded that most of the Mathematics and Science trainee teachers hold unfavourable perceptions towards the implementation of the PPSMI. Even though they acknowledge the significant roles that the English language play in the epoch of globalization, it seems that the use of the Malay language would be the best avenue to expediently transmit knowledge to students. Such findings are also evident in other studies wherein the Malay language is a much more preferred instructional mode than the English language. In this study, their perceptions towards the PPSMI policy are aggravated by the challenges posed by the PPSMI policy itself and students' poor English.

Thus, there are two important implications of the study in relation to the existence of the DLP in today's education system. First, this study further testifies the fact that the implementation of the PPSMI is not a complete failure as recognized by many previous researchers. The emergence of the DLP would be a platform to satisfy both Malay and English advocates in the teaching and learning of Mathematics and Science. It is unavoidable that such implementation would draw severe criticism but it is best to remember that the implementation of the DLP is in stark contrast to the PPSMI. The latter required all the stakeholders concerned to implement it by hook or by crook. Nonetheless, the DLP is not mandatory and it cannot be simply executed unless it fulfils four specified conditions. All in all, the DLP is geared towards fulfilling the language needs of the students without any of them being marginalised so that they would have an equal chance to develop their personal growth.

Second, there is a pressing need to improve the quality of English among students. It has been painstakingly researched by previous studies that having a poor command of English is undoubtedly detrimental to the future of the nation. The acute decline in English has long been a malignant disease since 1970. If this were to prolong without taking any immediate measures, the country would undoubtedly suffer domino effect in terms of its competitiveness and productivity in the future .Indeed, the proficiency of the English language is extremely worrying to the extent the plan of making English as a must pass subject effective in 2016 is put off till later time. Clinging to the national language in today's borderless world is not a viable option and this in turn requires everyone to be open minded and value the English language as much as he or she values the national language. As Tun Mahathir once said if English is primarily learnt to ensure the survival of the country, they are the emblem of true warriors of Malaysia. All of these clarify the government's standpoint to introduce the DLP, a two-pronged approach; a platform to boost English and a less radical mechanism of changing the people's mindset as seen in Menon (2016).

To conclude, it is best to note that the less successful PPSMI policy does give a rise to the DLP but with a different modus operandi. These discrepancies, as discussed in the previous paragraphs, are important to bring to the fore so that the DLP must not be mistakenly judged as the PPSMI policy. So, as for future research, it would be highly recommended if other researchers could delve into the effectiveness of the DLP by comparing the DLP students' achievements in Mathematics and Science with the non- DLP students.

\section{References}

Ali, M. \& Ismail, Z. (2006). Comprehension level of non-technical terms in Science: Are we Ready for Science in English. Jurnal Pendidik dan Pendidikan, (21): 73 - 83.

Arsad, M. S. M. (2015, October 31). Bertentangan dasar MBMMBI. Berita Harian.

Atan, A. (2016). DLP: Kerajaan tidak ambil iktibar kegagalan PPSMI. Retrieved from http://www.malaysiadateline.com/index.php/berita-list/15-berita/1905-dlp-kerajaan-tidak-ambil-iktibar- $\quad$ kegagalanppsmi

Aziz, R. M. R. A., \& Nair, R. (2015). Globalisation and the evolution of English language education in Malaysian secondary schools. In Bernard Spolsky and Kiwan Sung (Eds), Secondary School English in Asia: From policy to practice. New York: Routledge.

Ball, J. (2014). Children learn better in their mother tongue. Retrieved from http://www.globalpartnership.org/blog/children-learn-better-their-mother-tongue

Chan, S. H., \& Abdullah, A. N. (2015). Bilingualism in Malaysia. Language education policy and local needs. Pertanika J. Soc. Sci. Hum, 23(S), 55-70. 
David, M.K. \& Govindasamy, S. (2005). Negotiating a national language policy: Local need for Affirmative action versus commitment towards globalization. In A.S. Canagarajah (Ed.), Reclaiming the local in language policy and practice. Mahwah NJ: Lawrence Erlbaum.

Educational Ministry of Malaysia. (2015). Draf Versi 1.0 Program Dwibahasa: Dual Language Programme. Retrieved from http://coachmohdnoor.com/wp-content/uploads/2016/12/FAQ-DLP.pdf

English Language Standards \& Quality Council. (2016). English language education reform in Malaysia: The Roadmap 2015-2025.

Genesee, F. \& Fortune, T. W. (2014). Bilingual education and at-risk students. Journal of Immersion and Content Based Language Education, 2(2), 196-209.

Hamid, A. J. (2011, November 6). Overhaul nation's education policy. The Star, Retrieved from http://listserv.linguistlist.org/pipermail/lgpolicy-list/2011-November/013311.html

Haron, I., Gapor, L., Masran, M., N., Ibrahim, A., H. \& Nor, M. M. (2008). Kesan dasar Pengajaran Matematik dan Sains dalam Bahasa Inggeris. Retrieved from http://www.scribd.com/doc/11492280/PPSMI-Kajian-UPSI-April-2008Penuh

Hussain, K. S. K. \& Hamid, A. H. (2009, July 19). PPSMI satu kesilapan. Utusan Malaysia, Retrieved from http://ww1.utusan.com.my/utusan/info.asp? $=2009 \& d t=0719 \& s e c=R e n c a n a \& p g=r e+02 . h t m$

Idris, N., Cheong, L., S. Nor, N., M., Razak, A., Z., A. \& Saad, R. M. (2007). The professional preparation of Malaysian teachers in the implementation of teaching and learning of Mathematics and Science in English. Eurasia Journal of Mathematics, Science and Technology Education, 3(2), 101-110.

Isa, Z., Zakaria, A. M., Azlan, M. I., Noorani, M. S. M., Majid, N., Ismail, H., Jaaman, S. H., Darus, M., Nazar, R. M., Ramli, S. N., Suradi, N. R. M., Rambely, A. S., Ahmad, R., Din, U. K. S., Shahabuddin, F. A., Ismail, $\quad$ W. $\quad$ R., Mamat, N. J. Z., Muda, N., Abidin, N. Z., Hashim, I., Mustafa, Z. \& Ahmad, A. G. (2011). Students' Perceptions of the Implementation of Teaching and Learning of Science and Mathematics in English. Procedia Social and Behavioral Sciences, 18(2011), 361-366.

Jalaluddin, N. H. (2009). Why PPSMI Reversal Makes Sense. Retrieved from http://www. scribd.com/doc/17504214/Why-PPSMI-Reversal-Makes-Sense

Jalleh, J. (2012, September 26). Majority of teachers not proficient in English. The Star. Retrieved from http://www.thestar.com.my/news/nation/2012/09/26/majority-of-teachers-not-proficient-in-english/

Jamaluddin, K. (2008). Science and Maths in English-Alternative Views. http://educationmalaysia.blogspot.com/2008/09/science-and-math-in-english-alternative.html

Jantan, J. (2008). Persidangan meja bulat 4 PPSMI. Retrieved from http://drjj.uitm.edu.my/DRJJ/TOBIAS/DrJJ\%20PPSMI\%20article\%20181008.pdf

Joash, E, D, S. (2015). English proficiency crucial to progress, says Dr Mahathir. The Star, Retrieved from http://www.thestar.com.my/news/nation/2015/11/22/english-proficiency-dr-mahathir/

Kessler, C. \& Quinn M.E. (1987). Esl and Science learning. In J. Crandall (Ed.), ESL through content-area instruction. New Jersey: Prentice Hall.

Kili, K. A. (2015, June 20). Heed Sultan's call on English, Says Johor MCA. The Star, p. 14.

Kok, T. (2015, June 13). Heed Johor Sultan's Aadvice. The Star, p. 58.

Kulasagaran, P., Goon, J., Rajendram, R. \& Khor, Ann-Marie. (2014, October 19). Enhancing existing initiatives. The Star, Retrieved from http://www.thestar.com.my/news/education/2014/10/19/enhancing-existing-initiatives/

Lindholm-Leary,K. (2016). Students' perceptions of bilingualism in Spanish and Mandarin Dual Language Programs. International Multilingual Journal, 10(1), 59-70.

Majid, N., Jaaman, S. H., Darus, M., Nazar, R. M., Ramli, S, N. M., Suradi, N. R. M., Rambley, A. S., Ahmad, R., Din, U. K. S., Shahabuddin, F. A., Ali, Z. M., Rafee, N. M., Ismail, W. R., Mamat, N. J. Z., Muda, N., Abdidin, N. Z., $\quad$ Noorani, M. S. M., Zakaria, A.M., Isa, Z., Ismail, H., Mustafa, Z., Ahmad, A. G., Azlan, M. I. \& Hashim, I. (2011). The readiness of Science and Mathematics lecturers to teach in English from Students' Perspective. Procedia Social and Behavioural Sciences, 18, 342-347.

Menon, S. (2016, October 6). 841 schools expected to implement DLP. The Star. Retrieved from http://www.thestar.com.my/news/nation/2016/10/06/841-schools-expected-to-implement-dlp/

Mohandas, P. \& Rajaratnam, P. OC. (2015). A policy analysis of the delivery of primary and secondary school Mathematics and Science in English. Education Research and Perspectives, 4(2015), 246-285.

Muda, N., Ismail, W. R., Shahabuddin, F. A., Samsudin, H. B., Suradi, N. R. M., Majid, N., Ahmad, R., Rambley, A. S., Mamat, N. J. Z., Din, U. K. S., Jaaman, S. H. H., Hassan, N., Nazar, R. M., Mustafa, Z., Ali, Z. M., Isa, Z., Ismail, H., Zin, W. Z. W., Zahari, M., Abidin, N. Z., Salleh, A. R., Zakaria, A.M., Darus, M., Ahmad, A. G. \& Rafee, N. M. (2012). Teaching Science and Mathematics in English steering mastery in English students in UKM. Proceedia Social and Behavioral Sciences, 59(2012): 670-677. language amongst sciences 
Murali, R. S. N. (2015, November 9). 1,000 students drop out due to poor command of the language. The Star. Retrieved from http://www.thestar.com.my/news/nation/2015/11/09/poor-english-stops-medical-grads-1000-students-drop-out-due-to-poorcommand-of-the-language/

Nor, F. M. \& Aziz, M. A. (2008). ETeMS: The implications on learner. Retrieved from http://www.iiu.edu.my/ilc/?download=11-e08.pdf

Oh, E. (2015, July 25). Understanding Honda's drive for English. The Star, p. 11.

Onishi, N. (2010, July 25). As English spreads, Indonesians fear for their language. The New York Times. Retrieved from http://www.nytimes.com/2010/07/26/world/asia/26indo.html

Rahim, N. A. A. (2010). MBMMBI and PPSMI are two different animals. The Malaysian Insider. Retrieved from http://www.themalaysianinsider.com/mobile/breakingviews/article/MBMMBI-and-PPSMI-are-two-different-animalsNoor-Azimah-Abdul-Rahim

Rahim, N. A. A (2013, March 7). Be committed to English challenge. The Star. Retrieved from http://www.thestar.com.my/opinion/letters/2013/03/07/be-committed-to-english-challenge/

Pandian, A. \& Ramiah, R. (2004). Mathematics and Science in English: Teacher Voice. Retrieved from http://kajianberasaskansekolah.files.wordpress.com/2008/03 mathematics_and_science_in_english.pdf.

Piaw, C. Y. 2016. Mastering research methods $2^{\text {nd }}$ Edition. Shah Alam: Mc Graw Hill Education.

Pim, L. H. (2016, October 17). "Stupid" turn to education 30 years ago "stupid", says Adenan. The Borneo Post. Retrieved from http:/www.theborneopost.com/2016/10/17/cm-stupid-turn-to-education-30-years-ago- $\quad$ stupid-saysadenan/

Planas, N. \& Civil, M. (2013). Language-as-resource and language-as-political: tensions in the bilingual mathematics classroom. Mathematics Education Research Group of Australasia.

Reljic, G., Ferring, D., \& Martin, R. (2014). A Meta-Analysis on the effectiveness of bilingual programs in Europe. Review of Educational Research, XX(X), 1-37.

Ridhwan, A. (2009). Perhimpunan penulis-penulis muda Malaysia. Retrieved from http://1anwa ridhwan.blogspot.com/2009_05_01_archive.html.

Ahmad, R., Majid, N., Mamat, N. J. Z., Rambley, A. S., Muda, N., Jaaman, S. H. H., Suradi, N. R. M., Ismail, W. R., Shahabuddin, F. A., Roslinda, M. N., Samsudin, H. B., Zin, W. Z. W., Zahari, M. \& Mahmmod, N. (2012). Transformation of language in teaching and learning policy. Procedia Social and Behavioral Sciences, 59(2012), 685-691.

Salam, N. H. A., \& Shahrill, M. (2014). Examining classroom interactions in secondary Mathematics classrooms in Brunei Darussalam. Asian Social Science, 10(11), 92-103.

Saalbach, H., Eckstein, D., Andri, N., Hobi, R., \& Graber, RH. (2014). When language of instruction and language of application differ: Cognitive costs of bilingual mathematics learning. Learning and Instruction, 26(2013), 36-44.

Samah, A. A. (2008). The Development of English Language Policy in Malaysia: The New Policy on Science and Mathematics in the Medium of English. Unpublished $\mathrm{PhD}$ thesis, University of Sussex.

Selamat, A., Esa, A., Saad, S. S., \& Atim, A. (2011). Teaching and learning Mathematics and Science in English in primary schools in the state of Johor, Malaysia. Journal of Education, 16(2011), 61-73.

Thang, S. W. \& Olaybal, D. L. (2006). Creating and testing Science in English

The Star. (2015, October 6). Downfall due to poor English. Retrieved from http://www.thestar.com.my/news/nation/2015/10/06/downfall-due-to-poor-english-many-terengganu-top- studentsfare-badly-in-muet/website for Malaysian secondary one students. Malaysian Online Journal of Instructional Technology (MOJIT), 3(1), 36-42.

Thirusanku, J \& Yunus, M. M. (2014). Status of English in Malaysia. Asian Social Science, 10(14), 254-260.Yunus, M. M. \& Hern, G. H. (2011). Malaysian Undergraduates' perceptions and attitudes on bilingual education. Procedia Social and Behavioral Sciences, 15(2011), 2618-2622. 